\title{
YIELD AND QUALITY PARAMETERS OF WINTER AND SUMMER-SOWN DIFFERENT CAMELINA (Camelina sativa L.) GENOTYPES
}

\author{
Ahmet KINAY ${ }^{*}$, , Gungor YILMAZI , Samet AYISIGI ${ }^{2}$, Saziye DOKULEN ${ }^{1}$ \\ ${ }^{1}$ Tokat Gaziosmanpasa University, Faculty of Agriculture, Department of Field Crops, Tokat, TURKEY \\ ${ }^{2}$ Firat University, Vocational High School of Baskil, Elazı, TURKEY \\ ${ }^{*}$ Corresponding author: ahmet.kinay@gop.edu.tr
}

Received: 01.06.2018

\begin{abstract}
The present study was conducted to determine the performance of summer and winter-sown camelina lines in 2013-2014 and 2014-2015 growing seasons. In experiments, 11 camelina genotypes (Vinimik 17, PI304269, CR 476/65, CR 1674/90, Ames 26665, Ames 26667, Ames 26673, Ames 26676, Ames 26680, Ames 26686 and Ames 28372) were used as the plant materials. Plant height, number of pod per plant, number of seeds per pod, thousand-seed weight, seed yield, oil ratio and oil yield values were measured. The differences in investigated traits of the genotypes were found to be significant $(p<0.05)$. Winter sowings had better performance than summer sowings for yield and yield components. Winter-sown camelina plants were harvested at the end of May or at the beginning of June, which means that it is a good pre-plant for camelina. Average seed yields varied between $2.127-4.943$ ton $\mathrm{ha}^{-1}$ in winter sowings and between $0.582-4.609$ ton $\mathrm{ha}^{-1}$ in summer sowings; oil ratios varied respectively between $32.1-33.4 \%$ and between $24.3-35.1 \%$. It was concluded based on findings that camelina should be produced as winter-sown with Ames-26686 genotype. Furthermore, Ames26680, Ames-26686 and Ames 28372 genotypes could also be grown as summer-sown with quite reliable performance levels in years with sufficient spring precipitations.
\end{abstract}

Key words: Oil ratio, oil yield, seed yield, summer sowing, winter sowing

\section{INTRODUCTION}

Together with ever-increasing world population, food and energy demands are also increasing. Vegetable oils have a significant place in human nutrition, and they are also used in the energy industry. Fossil fuels are the primary source of energy industry, but there is an everincreasing interest in biofuels because of decreasing quantities of fossil fuels and environmental impacts of these fuels. Oilseeds are the primary raw material of biofuels. Therefore, production of oilseeds should be increased, and new oilseeds should be incorporated into cropping patterns (RTMCT, 2014; Ogut et al., 2014).

Studies on camelina accelerated in Turkey with the trails of USA Air Forces and Japan Airways for the potential use of camelina oil as a biofuel in planes (Onder, 2013). Camelina seeds are quite rich in polyunsaturated fatty acids, and they can be utilized as a different oil crop (Kurt and Seyis, 2008). Camelina biodiesel complies with TS EN 14214 standard (Ogut et al., 2013). Cetane number is 42.8 , oxidation stability is 1.3 hours at $110^{\circ} \mathrm{C}$, and iodine number is 152 (Ciubota-Rosie et al., 2013).

Camelina plants are resistant to cold weather and drought to a certain extent. They can be sown in winter and summer. They can also be considered to be used over the fallow lands (Yilmaz et al., 2014). As it was in various other plants, yield, yield components and biodiesel performance of camelina are also directly influenced by the region, cultivar, sowing time, norm and rate, fertilization and other cultural practices. For successful cultivation, effects of all these factors on camelina should be assessed with detailed researches (Urbaniak et al., 2007; Kumari et al., 2012; Schillinger et al., 2012; Arslan et al., 2014). Although camelina is primarily a summersown crop, it has some winter-resistant genotypes (Crowley and Fröhlich, 1998). Higher yields and oil ratios are obtained from winter-sown genotypes than summer-sown ones (Katar et al., 2012).

In a study carried out with 18 camelina cultivars under Montana conditions, average plant height of the cultivars was reported as $95.3 \mathrm{~cm}$, crop yield was reported as 2.59 ton ha ${ }^{-1}$, oil ratio was reported as $32.6 \%$ and oil yield as 0.844 ton $\mathrm{ha}^{-1}$ (Guy et al., 2014). The researcher obtained the highest seed yield (2.944 ton ha-1) and oil yield (0.961 ton $\mathrm{ha}^{-1}$ ) from SO cultivar (Mason, 2010). In another study, Toncea et al. (2013) investigated chemical characteristics of summer and winter-sown camelina cultivars at different locations under Romanian conditions between the years 2009-2013. In this study, oil ratios varied as between $29.3-46.3 \%$ for winter-sown cultivars 
and as between 33.4-49.6\% summer-sown cultivars. To be considered the cultivars, oil ratios ranged as between 31.1$45.8 \%$ for Camelia, as between $31.9-44.8 \%$ for Celena and as between 30.7-43.6\% for Lindo. As a result of research conducted by Yildirim and Onder (2016), the highest seed yield 1.979 ton $\mathrm{ha}^{-1}$ was obtained from $75 \mathrm{~kg}$ $\mathrm{ha}^{-1}$ dose of nitrogen and phosphorus, the highest oil ratio $29.33 \%$ was obtained from $150 \mathrm{~kg} \mathrm{ha}^{-1}$ dose of nitrogen and $100 \mathrm{~kg} \mathrm{ha}^{-1}$ dose of phosphorus.

This study was conducted to determine adaptation of different camelina genotypes to assess the response of winter and summer-sown to Tokat/Turkey ecological conditions. The aim of this study, superior camelina genotypes about yield and yield components were determined.

\section{MATERIALS AND METHODS}

To be used in experiments, 11 foreign-originated Camelina sativa L. lines (Vinimik 17, PI304269, CR 476/65, CR 1674/90, Ames 26665, Ames 26667, Ames 26673, Ames 26676, Ames 26680, Ames 26686 and Ames 28372) were supplied from Thrace Agricultural Research Institute as the plant material of the present study. Experiments were conducted randomized blocks experimental design with three replications in 2013-2014 and 2014-2015 vegetation periods over the experimental fields of Tokat Gaziosmanpasa University Agricultural Research and Implementations Center under TokatKazova conditions.

Climate data for experimental years are provided in Table 1. Long-term data indicate the highest total monthly precipitation for May. However, the highest monthly rainfall was observed in June of the first year and November and March of the second year. July is the hottest month both in long-term averages and in experimental years. The coldest month for long-term averages and in the second year of experiments was January, but it was December in the first year. Precipitation and temperature are the most significant climate parameters with substantial effects on experimental results. In the first year (2013-2014 vegetation period) rainfalls were lower, and temperatures were higher than the second year (2014-2015). The second year was more precipitated and colder than the first year (Table 1).

Table 1. Meteorological data during the vegetation period and their long term averages for the research area

\begin{tabular}{|c|c|c|c|c|c|c|c|c|c|c|c|}
\hline \multirow{2}{*}{ Parameters } & \multirow{2}{*}{ Years } & \multicolumn{9}{|c|}{ Months } & \multirow{2}{*}{$\begin{array}{c}\text { Total/ } \\
\text { Avarage }\end{array}$} \\
\hline & & October & November & December & January & February & March & April & May & June & \\
\hline \multirow{3}{*}{$\begin{array}{l}\text { Precipitation } \\
(\mathrm{mm})\end{array}$} & Long-term & 49 & 53 & 44 & 38 & 36 & 41 & 57 & 63 & 38 & 419 \\
\hline & 2013-2014 & 45 & 14 & 40 & 15 & 7 & 31 & 15 & 29 & 62 & 258 \\
\hline & 2014-2015 & 47 & 63 & 40 & 38 & 26 & 57 & 29 & 35 & 36 & 371 \\
\hline \multirow{3}{*}{ Humidity (\%) } & Long-term & 65 & 70 & 71 & 66 & 63 & 59 & 58 & 60 & 58 & 63 \\
\hline & $2013-2014$ & 58 & 65 & 74 & 67 & $*$ & $*$ & $*$ & 55 & 55 & 62 \\
\hline & 2014-2015 & 69 & 73 & 76 & 68 & 62 & 66 & 58 & 56 & 62 & 66 \\
\hline \multirow{3}{*}{$\begin{array}{l}\text { Avarage } \\
\text { temperature }\left(\mathrm{C}^{\circ}\right)\end{array}$} & Long-term & 14 & 7 & 3 & 2 & 3 & 7 & 13 & 16 & 20 & 9 \\
\hline & $2013-2014$ & 12 & 9 & -1 & 4 & 7 & 10 & 15 & 18 & 21 & 11 \\
\hline & 2014-2015 & 14 & 7 & 7 & 2 & 5 & 8 & 10 & 17 & 20 & 10 \\
\hline \multirow{3}{*}{$\begin{array}{l}\text { Maximum } \\
\text { temperature }\left(\mathrm{C}^{\circ}\right)\end{array}$} & Long-term & 20 & 13 & 7 & 6 & 8 & 13 & 19 & 23 & 27 & 15 \\
\hline & 2013-2014 & 31 & 22 & 15 & 17 & 22 & 24 & 28 & 34 & 34 & 25 \\
\hline & 2014-2015 & 25 & 22 & 18 & 15 & 19 & 23 & 27 & 36 & 31 & 24 \\
\hline \multirow{3}{*}{$\begin{array}{l}\text { Minimum } \\
\text { temperature }\left(\mathrm{C}^{\circ}\right)\end{array}$} & Long-term & 8 & 3 & 0 & -1 & -1 & 2 & 7 & 10 & 13 & 5 \\
\hline & 2013-2014 & 1 & -1 & -11 & -6 & -7 & -4 & -1 & 8 & 11 & -1 \\
\hline & 2014-2015 & 1 & -2 & -2 & -15 & -7 & -1 & -1 & 4 & 10 & -1 \\
\hline
\end{tabular}

Turkish State Meteorological Service, * not found

Experimental soils were loamy in texture, loamy and slightly alkaline in structure (Table 2). Soils were deficient in organic matter, sufficient in available phosphorus and potassium (Karaman and Brohi, 2004).

Table 2. Soil characteristics of the experimental areas

\begin{tabular}{ccccccc}
\hline Years & Texture & $\mathbf{p H}$ & $\mathbf{C a C O}_{\mathbf{3}}(\boldsymbol{\%})$ & $\mathbf{P}_{\mathbf{2}} \mathbf{O}_{\mathbf{5}}(\boldsymbol{\%})$ & $\mathbf{K}_{\mathbf{2}} \mathbf{O}(\boldsymbol{\%})$ & Organic Matter $(\boldsymbol{\%})$ \\
\hline $2013-2014$ & loamy & 7.74 & 11.85 & 7.44 & 43.01 & 0.4 \\
$2014-2015$ & loamy & 8.00 & 13.53 & 8.63 & 41.5 & 1.23 \\
\hline
\end{tabular}

Experiments were conducted in randomized blocks design with three replications. Winter sowings were performed on 08.10.2013 in the first year and on 15.10.2014 in the second year; summer sowings were performed on 05.03.2014 in the first year and on 28.02.2015 in the second year. Sowing rate was $10 \mathrm{~kg} \mathrm{ha}^{-}$ 1. Seeds were sown manually over five rows $20 \mathrm{~cm}$ apart from each other. Plots were $5 \mathrm{~m}$ long and $1 \mathrm{~m}$ wide. About $1.5 \mathrm{~m}$ spacing was provided between the plots. As the fertilizer, $80 \mathrm{~kg} \mathrm{ha}^{-1}$ pure nitrogen (Ammonium and Ammonium nitrate) and $30 \mathrm{~kg} \mathrm{ha}^{-1}$ sulfur were applied to experimental plots. All of the phosphorus $\left(\mathrm{P}_{2} \mathrm{O}_{5}\right)$ and potassium $\left(\mathrm{K}_{2} \mathrm{O}\right)$ (both as $40 \mathrm{~kg} \mathrm{ha}^{-1}$ pure) were used with sowing. Half of the nitrogen was applied at planting; the 
other half was implemented in the first week of March in winter sowings and in the last week of April in summer sowings. Experiments were not irrigated, and they were rainfed treatments. Manual weed control was practiced, and herbicide was not used for weed control. Insecticides were not used also since there were not any insect damages on plants. Harvest in winter sowings was performed on May 17, 2014 in the first year and 11.06.2015 in the second year; harvest in summer sowings was performed on July 3, 2014 in the first year and on June 29, 2015 in the second year. Plants were harvested manually and threshed with a thresher. Samples were taken from the threshed seeds, and oil ratios were determined with a soxhlet device. Experimental data were subjected to variance analysis with M-STATC software in accordance with randomized blocks experimental design. Means were compared with Duncan's multiple range test (Wang et al., 2013). Since the variations were not homogenous, years and periods were separately assessed in themselves.

\section{RESULTS AND DISCUSSION}

Differences in plant heights except for 2014-summer were found to be significant. Winter-2014 plant heights varied between 72.2 - $86.7 \mathrm{~cm}$ and winter-2015 plant heights varied between 102.9-124.4 cm. Summer-2014 plant heights varied between $30.1-36.6 \mathrm{~cm}$ and summer2015 plant heights varied between $76.1-91.9 \mathrm{~cm}$. Winter plant height averages (2014: $78.5 \mathrm{~cm} ; 2015: 116.4 \mathrm{~cm}$ ) were higher than summer plant height averages (2014: $34.7 \mathrm{~cm} ; 2015: 82.7 \mathrm{~cm}$ ) and 2015 plant heights were higher than 2014 plant heights. Higher precipitations throughout the vegetation period of the second year (2015) (Table 1) yielded tall plants.

Increase in plant height in winter sowing due to long vegetation period, but high temperature and drought stress in summer sow shortened plant length. The increase of plant length and the increase of capsule numbers with the number of side branches caused an increase of seed yield.

Number of pods per plant in the winter of 2014 varied between 61.2 - 102.3 and values varied between 58.6104.8 in the winter of 2015. Number of pods in the summer of 2014 varied between 37.2 - 44.4 and values varied between 58.4-93.9 in the summer of 2015. The differences in plant heights and number of pods per plant of the genotypes in sowing periods were found to be significant except for summer in 2014 (Table 3).

Table 3. Plant height and number of pods averages obtained by cultivating some camelina genotypes as winter and summer compared to years

\begin{tabular}{|c|c|c|c|c|c|c|c|c|}
\hline \multirow{3}{*}{ Genotypes } & \multicolumn{4}{|c|}{ Plant height $(\mathrm{cm})$} & \multicolumn{4}{|c|}{ Number of pods plant ${ }^{-1}$} \\
\hline & \multicolumn{2}{|c|}{2014} & \multicolumn{2}{|c|}{2015} & \multicolumn{2}{|c|}{2014} & \multicolumn{2}{|c|}{2015} \\
\hline & Winter* & Summer & Winter* & Summer* & Winter* & Summer & Winter* & Summer* \\
\hline Vinimik 17 & $75.0 \mathrm{de}$ & 33.7 & $118.8 \mathrm{ab}$ & $91.9 \mathrm{a}$ & $65.8 \mathrm{de}$ & 37.5 & $82.1 \mathrm{ab}$ & $77.8 \mathrm{ab}$ \\
\hline PI304269 & $78.5 \mathrm{bc}$ & 34.3 & $113.7 \mathrm{~b}$ & $81.1 \mathrm{c}$ & $72.5 \mathrm{~cd}$ & 43.8 & $104.8 \mathrm{a}$ & $61.1 \mathrm{~b}$ \\
\hline CR 476/65 & $77.8 \mathrm{~cd}$ & 34.5 & $121.3 \mathrm{ab}$ & $81.6 \mathrm{c}$ & $70.8 \mathrm{~cd}$ & 37.5 & $58.6 \mathrm{~b}$ & $63.5 \mathrm{~b}$ \\
\hline CR 1674/90 & $81.3 \mathrm{~b}$ & 35.8 & $117.1 \mathrm{ab}$ & $87.1 \mathrm{ab}$ & $68.5 \mathrm{~cd}$ & 41.3 & $88.8 \mathrm{ab}$ & $83.3 \mathrm{ab}$ \\
\hline Ames 26665 & $79.6 \mathrm{bc}$ & 34.5 & $112.8 \mathrm{~b}$ & $80.2 \mathrm{abc}$ & $85.8 \mathrm{~b}$ & 40.6 & $70.7 \mathrm{ab}$ & $72.2 \mathrm{ab}$ \\
\hline Ames 26667 & $72.2 \mathrm{e}$ & 35.8 & $120.3 \mathrm{ab}$ & $83.9 \mathrm{abc}$ & $82.3 \mathrm{~b}$ & 43.0 & $75.5 \mathrm{ab}$ & $78.1 \mathrm{ab}$ \\
\hline Ames 26673 & $79.5 \mathrm{bc}$ & 35.1 & $121.6 \mathrm{ab}$ & $86.5 \mathrm{ab}$ & $82.9 \mathrm{~b}$ & 37.8 & $75.5 \mathrm{ab}$ & $72.3 \mathrm{ab}$ \\
\hline Ames 26676 & 79.9 bc & 36.1 & $113.8 \mathrm{~b}$ & $82.6 \mathrm{abc}$ & $74.3 \mathrm{c}$ & 41.3 & $92.2 \mathrm{ab}$ & $58.4 \mathrm{~b}$ \\
\hline Ames 26680 & 86.7 a & 36.6 & $113.2 \mathrm{~b}$ & $77.0 \mathrm{c}$ & $102.3 \mathrm{a}$ & 44.4 & $92.2 \mathrm{ab}$ & $83.6 \mathrm{ab}$ \\
\hline Ames 26686 & $78.8 \mathrm{bc}$ & 34.9 & $124.4 \mathrm{a}$ & $81.4 \mathrm{abc}$ & $83.3 \mathrm{~b}$ & 42.9 & $67.8 \mathrm{~b}$ & $93.9 \mathrm{a}$ \\
\hline Ames 28372 & $74.0 \mathrm{e}$ & 30.1 & $102.9 \mathrm{c}$ & $76.1 \mathrm{c}$ & $61.2 \mathrm{e}$ & 37.2 & $74.3 \mathrm{ab}$ & $76.1 \mathrm{ab}$ \\
\hline Avarage & 78.5 & 34.7 & 116.4 & 82.7 & 77.2 & 40.7 & 80.1 & 74.6 \\
\hline LSD (\%5) & 4.3 & $\mathrm{~ns}$ & 9.7 & 6.07 & 10.4 & ns & 3.6 & 29.5 \\
\hline
\end{tabular}

*p<0.05, ns: non-significant, LSD: Least Significant Difference

Winters seedlings in plants were found to encourage more capsule formation in plants than in summer seedlings in plants (Urbaniak et al., 2007). The length of side branches of winter sowing increased the number of flowers. This increase in the number of flowers affected the number of capsules and seeds positively.

Significant differences were observed in seed number per pod of the genotypes. The number of seeds per pod varied between 6.1-15.9, and the most significant values were obtained from CR 476/65 line. The differences in thousand-seed weights of the genotypes were also found to be significant (Table 4). About thousand-seed weight, based on years and sowing periods, CR 1674/90 line was placed in the first group (Table 4).

It is effective to store more photosynthesis products by evaluating the environmental factors and the growth of the plants in a thousand seed weights. In this study, plants planted in winter showed a better development than those planted in summer regarding all their components. As a result, the seeds in the plants have become bigger. 
Table 4. Number of seeds per pod and thousand-seed weight averages obtained by cultivating some camelina genotypes as winter and summer compared to years

\begin{tabular}{|c|c|c|c|c|c|c|c|c|}
\hline \multirow{3}{*}{ Genotypes } & \multicolumn{4}{|c|}{ Number of seeds pod $^{-1}$} & \multicolumn{4}{|c|}{ Thousand-seed weight (g) } \\
\hline & \multicolumn{2}{|c|}{2014} & \multicolumn{2}{|c|}{2015} & \multicolumn{2}{|c|}{2014} & \multicolumn{2}{|l|}{2015} \\
\hline & Winter* & Summer* & Winter* & Summer* & Winter* & Summer* & Winter* & Summer* \\
\hline Vinimik 17 & $14.8 \mathrm{ab}$ & $8.5 \mathrm{bc}$ & $12.9 \mathrm{ab}$ & $12.9 \mathrm{ab}$ & $1.05 \mathrm{~b}$ & $0.96 \mathrm{a}$ & $1.09 \mathrm{ab}$ & $1.26 \mathrm{~b}$ \\
\hline PI304269 & $10.9 \mathrm{de}$ & $8.4 \mathrm{bc}$ & $11.4 \mathrm{~b}$ & $13.8 \mathrm{ab}$ & $1.02 \mathrm{bcd}$ & 0.99 & $1.10 \mathrm{ab}$ & $1.27 \mathrm{ab}$ \\
\hline CR 476/65 & 15.7 & 9.6 & $14.6 \mathrm{a}$ & $15.6 \mathrm{a}$ & $0.94 \mathrm{de}$ & 0.43 & $0.92 \mathrm{e}$ & $1.07 \mathrm{c}$ \\
\hline CR 1674/90 & 10.0 & $7.4 \mathrm{~d}$ & $13.5 \mathrm{ab}$ & $13.7 \mathrm{ab}$ & $1.14 \mathrm{a}$ & 0.93 & $1.20 \mathrm{a}$ & $1.34 \mathrm{a}$ \\
\hline Ames 26665 & 13.0 & $7.7 \mathrm{~cd}$ & $14.1 \mathrm{ab}$ & $13.2 \mathrm{ab}$ & 0.99 bcd & $0.84 \mathrm{~b}$ & $1.01 \mathrm{~b}-\mathrm{e}$ & $1.08 \mathrm{c}$ \\
\hline Ames 26667 & 14.0 & $8.1 \mathrm{~cd}$ & $14.4 \mathrm{a}$ & $15.1 \mathrm{a}$ & $0.89 \mathrm{e}$ & $0.73 \mathrm{c}$ & $0.90 \mathrm{e}$ & $0.98 \mathrm{~d}$ \\
\hline Ames 26673 & 13.8 & $8.3 \mathrm{~cd}$ & $13.0 \mathrm{ab}$ & $15.9 \mathrm{a}$ & $1.06 \mathrm{~b}$ & 0.54 & $1.01 \mathrm{bcd}$ & $1.28 \mathrm{ab}$ \\
\hline Ames 26676 & 13.9 & $7.9 \mathrm{~cd}$ & $11.8 \mathrm{ab}$ & $11.7 \mathrm{~b}$ & $1.17 \mathrm{a}$ & $0.66 \mathrm{~d}$ & $1.01 \mathrm{bcd}$ & $1.29 \mathrm{ab}$ \\
\hline Ames 26680 & $11.3 \mathrm{~d}$ & $6.1 \mathrm{e}$ & $11.9 \mathrm{ab}$ & $15.5 \mathrm{a}$ & $1.02 \mathrm{bcd}$ & $0.74 \mathrm{c}$ & 0.99 cde & $1.11 \mathrm{c}$ \\
\hline Ames 26686 & $13.2 \mathrm{c}$ & $9.0 \mathrm{ab}$ & $11.5 \mathrm{~b}$ & $14.5 \mathrm{ab}$ & $1.04 \mathrm{bc}$ & $0.96 \mathrm{a}$ & $1.03 \mathrm{bcd}$ & $1.10 \mathrm{c}$ \\
\hline Ames 28372 & 13.1 & $8.0 \mathrm{~cd}$ & $13.7 \mathrm{ab}$ & $14.7 \mathrm{ab}$ & 0.96 cde & $0.95 \mathrm{a}$ & $0.97 \mathrm{de}$ & $1.23 \mathrm{~b}$ \\
\hline Avarage & 13.1 & 8.1 & 13.0 & 14.2 & 1.02 & 0.79 & 1.02 & 1.18 \\
\hline LSD (\%5) & 1.5 & 0.8 & 2.88 & 3.28 & 0.12 & 0.06 & 0.11 & 0.076 \\
\hline
\end{tabular}

*p<0.05, LSD: Least Significant Difference

Seed yields of the genotypes in 2014 winter sowings varied between $1.364-2.546$ ton ha ${ }^{-1}$ with an average value of 2.127 ton ha ${ }^{-1}$ and seed yields of the summer sowings varied between $0.344-0.798$ ton ha $^{-1}$ with an average value of 0.582 ton $\mathrm{ha}^{-1}$ (Table 5). In the second year of the experiments (2015), seed yields of winter sowings varied between 4.417-5.477 ton $\mathrm{ha}^{-1}$ with an average value of 4.943 ton ha $^{-1}$ and seed yields of summer sowings varied between $3.947-5.095$ ton ha ${ }^{-1}$ with an average value of 4.609 ton ha ${ }^{-1}$ (Table 5). Considering the sowing periods, it was observed that winter sowings had better performance than the summer sowings (Katar et al., 2012). However, in case of sufficient precipitation and temperature in spring (as it was in 2015 of the experiments), summer sowings may have a close performance to winter sowings.

Table 5. Number of seeds per pod and thousand-seed weight averages obtained by cultivating some camelina genotypes as winter and summer compared to years

\begin{tabular}{|c|c|c|c|c|c|c|c|c|c|c|c|c|c|}
\hline \multirow{4}{*}{$\begin{array}{l}\text { Genotypes } \\
\text { Vinimik } 17\end{array}$} & \multicolumn{5}{|c|}{ Seed yields (ton ha $\left.^{-1}\right)$} & \multicolumn{8}{|c|}{ Oil ratio $(\%)$} \\
\hline & \multicolumn{2}{|c|}{2014} & \multicolumn{3}{|c|}{2015} & \multicolumn{4}{|c|}{2014} & \multicolumn{4}{|c|}{2015} \\
\hline & \multirow{2}{*}{$\frac{\text { Winter* }}{1.364} \mathrm{~h}$} & \multirow{2}{*}{$\frac{\text { Summer* }}{0.545 \mathrm{~d}}$} & \multirow{2}{*}{$\frac{\text { Winter }}{5.477}$} & \multicolumn{2}{|c|}{ Summer* } & \multicolumn{2}{|c|}{ Winter* } & \multicolumn{2}{|c|}{ Summer* } & \multicolumn{2}{|c|}{ Winter* } & \multicolumn{2}{|c|}{ Summer* } \\
\hline & & & & 4.977 & $\mathrm{ab}$ & 32.3 & bcd & 25.9 & c & 31.3 & bcd & 37.3 & $\mathrm{a}$ \\
\hline PI304269 & $2.025 \mathrm{f}$ & $0.613 \mathrm{c}$ & 4.432 & 4.609 & $a b c$ & 32.0 & $\mathrm{~cd}$ & 27.8 & $\mathrm{bc}$ & 32.4 & $\mathrm{bc}$ & 37.1 & $\mathrm{a}$ \\
\hline CR 476/65 & $2.324 \mathrm{bc}$ & $0.494 \mathrm{e}$ & 4.417 & 4.850 & $\mathrm{ab}$ & 31.2 & d & 16.3 & $\mathrm{e}$ & 32.3 & bcd & 35.8 & $a b$ \\
\hline CR 1674/90 & $2.139 \mathrm{e}$ & $0.631 \mathrm{c}$ & 5.285 & 4.495 & $a b c$ & 33.8 & $\mathrm{bc}$ & 23.5 & $\mathrm{~d}$ & 29.8 & $\mathrm{~d}$ & 31.9 & $\mathrm{c}$ \\
\hline Ames 26665 & $2.247 \mathrm{~cd}$ & $0.599 \mathrm{c}$ & 4.814 & 4.254 & bc & 34.2 & $\mathrm{~b}$ & 28.2 & $\mathrm{bc}$ & 30.7 & $\mathrm{~cd}$ & 31.6 & $\mathrm{c}$ \\
\hline Ames 26667 & $2.339 \mathrm{~b}$ & $0.697 \mathrm{~b}$ & 4.888 & 4.434 & $a b c$ & 33.7 & $\mathrm{bc}$ & 22.0 & $\mathrm{~d}$ & 31.5 & bcd & 34.1 & $\mathrm{bc}$ \\
\hline Ames 26673 & 2.220 & $0.456 \mathrm{e}$ & 5.046 & 4.679 & $a b c$ & 34.3 & $\mathrm{~b}$ & 18.4 & e & 31.5 & bcd & 36.3 & $a b$ \\
\hline Ames 26676 & $2.006 \mathrm{f}$ & $0.491 \mathrm{e}$ & 4.840 & 4.594 & $a b c$ & 31.9 & $\mathrm{~cd}$ & 18.0 & e & 32.4 & $\mathrm{bc}$ & 32.1 & $\mathrm{c}$ \\
\hline Ames 26680 & $2.546 \mathrm{a}$ & $0.737 \mathrm{~b}$ & 5.151 & 3.947 & $\mathrm{c}$ & 33.3 & $\mathrm{bc}$ & 26.5 & $\mathrm{c}$ & 31.8 & bcd & 35.9 & $a b$ \\
\hline Ames 26686 & $2.361 \mathrm{~b}$ & $0.798 \mathrm{a}$ & 4.921 & 4.768 & $a b$ & 37.9 & $\mathrm{a}$ & 31.3 & $\mathrm{a}$ & 35.5 & $\mathrm{a}$ & 36.3 & $a b$ \\
\hline Ames 28372 & $1.824 \mathrm{~g}$ & $0.344 \mathrm{f}$ & 5.101 & 5.095 & $\mathrm{a}$ & 32.8 & bcd & 29.5 & $\mathrm{~b}$ & 33.4 & $a b$ & 37.2 & $\mathrm{a}$ \\
\hline Avarage & 2.127 & 0.582 & 4.943 & 4.609 & & 33.4 & & 24.3 & & 32.1 & & 35.1 & \\
\hline LSD (\%5) & 11.79 & 4.86 & ns & 7.53 & & 2.88 & & 2.40 & & 2.58 & & 2.96 & \\
\hline
\end{tabular}

${ }^{*} \mathrm{p}<0.05$, ns: non-significant, LSD: Least Significant Difference

Considering the seed yields of the genotypes, the most significant values were obtained from Ames-26680 genotypes in winter-2014, from Ames-26686 in summer2014, from Vinimik-17 in winter-2015 and Ames-28372 in summer-2015. Genotypes had different responses based on environmental conditions (Guy et al., 2014). As the average of two years, Ames-26680 (with an average seed yield of 3.849 ton $\mathrm{ha}^{-1}$ ) had higher yield in winter sowings and Ames-26686 (with an average seed yield of 2.783 ton $\mathrm{ha}^{-1}$ ) had higher yield in summer sowings than the other genotypes.

Oil ratio of Ames-26686 genotype in different years and sowing periods were respectively observed as 37.9 , $31.3,35.5$ and $36.3 \%$ and these values were higher than the values of other genotypes (Table 5). However, when the conditions got better (as it was in summer-2015), Vinimik-17 (37.3\%), PI-304269 (37.1\%) and Ames-28372 $(37.2 \%)$ genotypes had also high oil ratios (Table 6). 
Table 6. Comparison of the oil yield averages obtained by cultivating some camelina genotypes as winter and summer

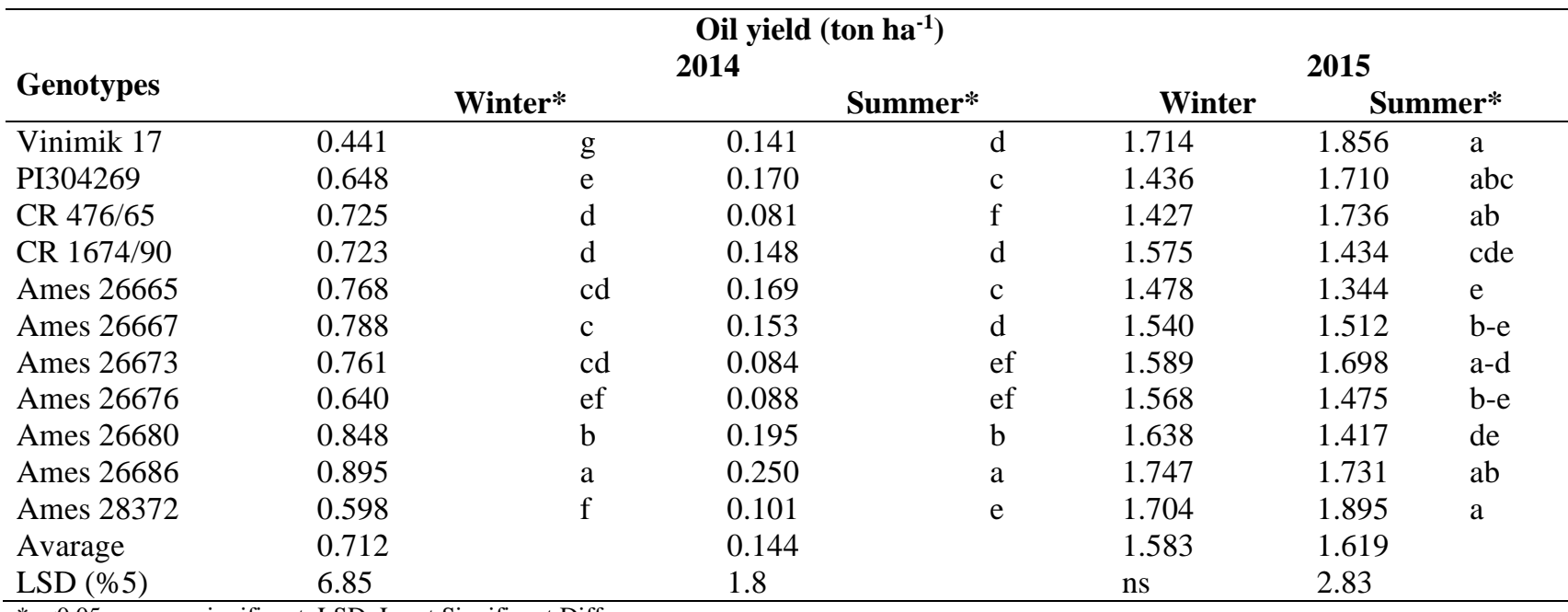

${ }^{*} \mathrm{p}<0.05$, ns: non-significant, LSD: Least Significant Difference

Oil yields of the genotypes varied in a quite broad range $\left(0.081-1.895\right.$ ton $\left.\mathrm{ha}^{-1}\right)$. Considering the years and sowing periods together, it was observed that Ames-26686 had the greatest and the most stable oil yield. This genotype which was placed in the first group for oil yield also had the first ranks in seed yield. About oil yield per hectare, Ames-26686 had better performance in the first year and Ames-28372 in the second year. The genotype Ames-26686 with superior characteristics for seed yield and oil ratio also had the most excellent oil yield. Because of the temperature stress observed during the flowering period in summer sowing, oil physiology has been affected negatively in this situation.

\section{CONCLUSION AND RECOMMENDATIONS}

Present findings, obtained from summer and winter sowings for two years under Tokat ecological conditions, revealed that winter sowings had better performance than summer sowings and there were not any severe cold damages even at minimum winter temperatures of $-6,-7$, 11 and $-12^{\circ} \mathrm{C}$. Because of insufficient precipitations and higher maximum and average temperatures in spring of 2014, quite low yield levels were observed in summer sowings. Dryer conditions in spring created heat stress on plants and resulted in shorter plants with less number of pods and consequently fewer yield. On the other hand, sufficient precipitations and moderate temperatures in 2015 increased the yield levels both in summer and winter sowings and also reduced the difference in seed yields of winter and summer sowings. It was also observed in this study that camelina left the field early; thus it was concluded that camelina could be a well-precursor crop in cropping patterns. Harvest was performed on $17^{\text {th }}$ of May in the first year with insufficient precipitation and heat stress and on $11^{\text {th }}$ of June in the second year.

It was concluded based on present findings that camelina could be produced as winter-sown under Tokat ecological conditions, but it can also be grown as summersown in years with sufficient spring precipitations. Among the investigated lines, Ames-26680, Ames-26686 and
Ames 28372 with better performance for seed yield and oil ratio than the other genotypes.

\section{LITERATURE CITED}

Arslan, Y., I. Subası, D. Katar, R. Kodas and H. Keyvanoglu. 2014. Effect of different levels of nitrogen and phosphorus on the yield and yield component of false flax (Camelina sativa L.) Crantz). Anadolu Journal of Agricultural Science 29(3): 231-239.

Ciubota-Rosie, C., J.R. Ruiz, M.J. Ramos and A. Pérez. 2013. Biodiesel from Camelina sativa: A comprehensive characterisation, Fuel, 105: 572-577

Crowley, J.G and A. Fröhlich. 1998. Factors Affecting the Composition and Use of Camelina. Crops Research Centre, Oak Park, Carlow. ISBN 1901138666.

Guy, S.O., D.J. Wysocki, W.F. Schillinger T.G. Chastain, R.S. Karow, K. Garland-Campbell and I.C. Burke. 2014. Camelina: Adaptation and performance of genotypes. Field Crops Research, 155, 224-232. (Accessed May 18, 2017)

Karaman, M.R. and A. Brohi. 2004. Limit values by methods of soil nutrient found. Agriculture Industry Environment Proceedings, Department Annex Tables, Nobel Publishing.

Katar, D., Y. Arslan and I. Subas1. 2012. Effect of different sowing dates on yield and yield components of false flax (Camelina sativa (L.) Crantz) under Ankara condition, Journal of Agricultural Faculty of Ataturk University, 43(1): 23-27.

Kurt, O. and F. Seyis. 2008. An alternative oilseed crop: Camelina [Camelina sativa (L.) Crantz]. Journal of Fac. of Agric., OMU, 23(2):116-120.

Kumar1, A., M. Mohsin, M.C. Arya, P.K. Josh1 and Z. Ahmed. 2012. Effect of spacing on Camelina sativa: A new biofuel crop in India. The Bioscan, 7(4): 575-577.

Mason, H. 2010. Statewide camelina variety evaluation. http://ag.montana.edu/nwarc/research.pdf (Accesed March 17, 2017).

Ogut, H., M. Onder, H. Oguz and S. Bacak. 2013. Biodiesel Production From Camelina (Camelina sativa L.) Crantz) Oil. 3rd National Workshop on Energy Agriculture and Biofuels, Proceedings Book, pp. 45-49.

Ogut, H., H. Oguz, S. Bacak, F. Aydın, S. Uygun, Y. Arslan and I. Subas1. 2014. Investigation of the Technical Properties of Pelemir Biodiesel. Energy Agriculture and Biofuels 4 . National Workshop Report Book, pp: 45-49. 
Onder, M. 2013. Camelina (Camelina sativa L. (Crantz)) A New Oil Plant That Can Be Cultivated In KOP Region. National KOP Regional Development Symposium, November 14-16, 2013 Konya-Turkey.

RTMCT, 2014. Republic of Turkey Ministry of Customs and Trade. Sunflower Report. http://english.gtb.gov.tr/ (Accesed Arpril 12, 2017).

Schillinger, W.F., D.J. Wysocki, T.G., Chastainc, S.O. Guy and R.S. Karow. 2012. Camelina: planting date and method effects on stand establishment and seed yield. Field Crops Research 130: 138-144.

Urbaniak, S.D., C.D. Caldwell, V.D. Zheljazkov, R. Lada, and L. Luan. 2007. The effect of cultivar and applied nitrogen on the performance of Camelina sativa $\mathrm{L}$. in the maritime provinces of Canada. Can. J. Plant Sci., 88: 111-119.
Toncea, I., D. Necserıu, T. Prisecaru, L.N. Balint, M.I. Ghilvacs and M. Popa. 2013. The seed's and oil composition of camelia-first romanian cultivar of Camelina (Camelina sativa, L. Crantz), Romanian Biotechnological Letters, 18(5): 8594-8602.

Wang, X., G. Feng, Z. Deng, W. Wang and L. Jin . 2013. Microsporogenesis and microgametogenesis of male-sterile mutant $m s 1$ in alfalfa, Crop Science, 53: 679-687.

Yildirim, H. and M. Onder. 2016. Effects of fertilizer doses on some of the yield and quality components in camelina (Camelina sativa L. Crantz), Selcuk Journal of Agricultural Sciences, 3(1): 117-122.

Yilmaz, G., A. Kinay and S. Ayisigi. 2014. Description and growing of camelina (Camelina sativa L.) plant. Energy Agriculture and Biofuels 4th National Workshop, 195-201. 